\author{
WITOLD WARCHOLIK \\ Uniwersytet Pedagogiczny w Krakowie, Polska / Pedagogical University of Krakow, Poland \\ Dorota CHMIELOWSKA \\ Uniwersytet Pedagogiczny w Krakowie, Polska / Pedagogical University of Krakow, Poland
}

\title{
Tropienie użytkowe jako forma rekreacii ruchowej w Polsce
}

\section{Mantrailing as a form of physical recreation in Poland}

\begin{abstract}
Streszczenie: Celem pracy była charakterystyka osób uprawiających tropienie użytkowe (mantrailing) w Polsce. Profil uczestnika i motywy uprawiania mantrailingu, określone na podstawie wyników badań ankietowych, zostały uzupełnione definicjami i aktualnym stanem wiedzy na temat tropienia użytkowego. Zwrócono uwagę na konieczność podjęcia dalszych badań, przyczyniających się do lepszego poznania i zrozumienia tej dynamicznie rozwijającej się formy rekreacji. Podstawowymi motywami uprawiania mantrailingu w Polsce jest określenie potrzeb i predyspozycji psa oraz chęć poznania jego cech bezpośrednio w warunkach pracy w terenie. Dla amatorów tropienia użytkowego zdawanie egzaminów i uzyskiwanie certyfikatów w tym zakresie nie jest istotne, podobnie jak aspekt rywalizacji między ich psami. Zaliczają mantrailing do całorocznych czynności plenerowych, w każdych warunkach terenowych. Uprawiają go najczęściej raz w tygodniu, ze względu na intensywność wysiłku zaliczając do czynności średnio intensywnych, a ze względu na stopień złożoności technicznej - do średnio trudnych. Zdecydowana większość osób uprawiających tropienie użytkowe jest sprawna fizycznie i podobnie jak w większości aktywności związanych z psami, liczebnie przeważają kobiety. Listę ras psów mantrailingowych cechuje ogromna różnorodność. W większości opinii brak też zdecydowanych wskazań ras preferowanych w tropieniu użytkowym. Głównymi czynnikami mogącymi negatywnie wpływać na popularyzowanie mantrailingu w Polsce są ograniczenia czasowe i finansowe.
\end{abstract}

\begin{abstract}
The aim of the study was to identify people practising tracking (mantrailing) on the territory of Poland. The profile and motives for practicing mantrailing, determined on the basis of survey results, have been supplemented with definitions and the current state of knowledge on mantrailing. Attention was paid to the necessity of undertaking further research contributing to better knowledge and understanding of this dynamically developing form of recreation. The main motives for practicing mantrailing in Poland are to determine the needs and predispositions of a dog and the desire to learn about its features directly in the field work conditions. For amateurs of mantrailing, passing exams and obtaining certificates in this field is not crucial, neither is the aspect of competition between their dogs. They treat mantrailing as a year-round outdoor activity, in all field conditions. They practice it usually once a week, classifying it due to the intensity of the effort as medium intensive, and due to the level of technical complexity as medium difficult. The vast majority of people practicing mantrailing are physically fit and, as in most dog-related activities, the largest number of them are women. The list of mantrailing dog breeds is greatly diverse. In most opinions, there is also a lack of strong indications of the breeds preferred in mantrailing. The main inhibitors of this activity in Poland are time constraints and financial factors.
\end{abstract}


Słowa kluczowe: aktywność fizyczna; mantrailing; rekreacja; sporty kynologiczne; szkolenie psów; tropienie użytkowe

Keywords: dog sports; dog training; mantrailing; physical activity; recreation

Otrzymano: 18 grudnia 2020

Received: 18 December 2020

Zaakceptowano: 13 lutego 2021

Accepted: 13 February 2021

\section{Sugerowana cytacja / Suggested citation:}

Warcholik, W., Chmielowska, D. (2021). Tropienie użytkowe jako forma rekreacji ruchowej w Polsce. Prace Komisji Geografii Przemysłu Polskiego Towarzystwa Geograficznego, 35(1), 123-136, doi: 10.24917/20801653.351.9

\section{WSTĘP}

Węch psa jest powszechnie wykorzystywany od bardzo dawna w ratownictwie, detekcji, myślistwie, stróżowaniu, a także od niedawna w rekreacji i sportach kynologicznych. Psy znajdują zastosowanie do wykrywania zapachów zarówno niebiologicznych, do których zaliczają się między innymi materiały wybuchowe i narkotyki, jak i biologicznych, takich jak zapach poszukiwanych przestępców, zaginionych lub martwych osób, komórek rakowych, feromonów innych gatunków zwierząt (Cichy i in., 2018). Właściwości zapachów, reguły rozprzestrzeniania oraz możliwości ich identyfikacji badane są przy użyciu najnowocześniejszych metod i sprzętu, a szkolenie psów w zakresie tropienia nadal uważa się za najtrudniejszą spośród wszystkich form psiej aktywności. Można skłonić psa do tego, by siadł, do reakcji obronnej, ale nigdy nie zmusi się go do tropienia (Ščučka, 2020). Sporty kynologiczne to jedna z form aktywności ruchowej, która obecnie skupia bardzo liczną grupę amatorów na świecie (Niewiadomska, Makris, 2015). W Polsce coraz większym zainteresowaniem cieszą się agility, frisbee, flyball, czy też obedience (Jastrzębska, Gugołek, Strychalski, 2017a).

W języku potocznym funkcjonuje określenie sportu z wykorzystaniem zwierząt, jednak sport to ćwiczenia i gry mające na celu rozwijanie sprawności fizycznej i jej manifestację. Uprawiane są według ustalonych reguł, często przy współzawodnictwie w dążeniu do osiągnięcia jak najlepszych wyników. Żadna z popularnych definicji i koncepcji sportu (ludyczna, agonistyczna, pedagogiczna) nie uwzględnia sportów uprawianych razem ze zwierzętami lub też przez same zwierzęta (Strychalski, Gugołek, Jastrzębska, 2016). Cytując za Wolańską (1997), człowiek oddaje się rekreacji z własnej chęci, w czasie wolnym, dla wypoczynku, odnowy sił, przyjemności i rozwoju własnej osobowości oraz kreacji zdrowia. Podobnie A. Dąbrowski (2006) rekreację ruchową określa jako wszelkie akceptowane społeczne formy fizycznej aktywności ludzi, mające miejsce w czasie wolnym, podejmowane dobrowolnie, bezinteresownie i dla przyjemności, służące odnowie i umacnianiu sił człowieka, aktywnej i różnorodnej samorealizacji o cechach zabawy. Rekreację ruchową rozumiemy jako zajęcia aktywizujące ruchowo, sportowo, turystycznie, zabawowo, którym człowiek oddaje się z własnej chęci, w czasie wolnym, dla realizacji potrzeb wewnętrznych (Kwilecka, 2006).

Celem pracy było scharakteryzowanie osób uprawiających tropienie użytkowe (mantrailing) w Polsce. Przeprowadzone badania ankietowe umożliwiły zdefiniowanie motywów i zalet uprawiania tej formy współpracy psa i człowieka. W oparciu o analizę dostępnej literatury przedmiotu scharakteryzowano mantrailing i zwrócono uwagę 
na konieczność podjęcia badań przyczyniających się do lepszego poznania tropienia użytkowego - nowej i dynamicznie rozwijającej się formy rekreacji na terenie Polski.

Psy, jako gatunek często wykorzystywany przez człowieka w celach sportowych i rekreacyjnych, pojawiają się w literaturze przedmiotu w wielu kontekstach. Są to zarówno prace zawierające przegląd kynologii sportowej z uwzględnieniem szeregu nowych form rekreacji i sportu z udziałem psów (Jastrzębska, Gugołek, Strychalski, 2017a, 2017b; Strychalski i in., 2016), jak i poruszające problematykę aktywności psa, opartych na węchu (Dłużewska i in., 2015; Niewiadomska, 2018). Szersze charakterystyki dotyczą m.in. dogtrekkingu (Dłużewska i in., 2015), agility (Theby, Hares, 2010) i obedience (Sjösten, 2005). Kontrowersyjnym problemem poruszanym w opracowaniach jest hodowla tzw. ras ekstremalnych (Jastrzębska, Gugołek, Strychalski, 2017b; Steiger 2006). Zagadnienia wyboru psa do tropienia, motywacji do pracy węchowej i oceny postępów w tropieniu zawarte są m.in. w pracach Górnego (2010) i Johnson (2003). Wyniki badań dotyczących codziennej aktywności sportowo-rekreacyjnej posiadaczy psów wskazują na wzrost ich aktywności fizycznej (Christian i in., 2013; Cutt i in., 2007; McNicholas, Collis, 2000; Teodorowicz, Woźniewicz-Dobrzyńska, 2014). Posiadanie psa wykracza daleko poza fizyczne korzyści właściciela (Cutt i in., 2008; Guéguen, Ciccotti, 2008; McNicholas i in., 2005). Zagadnienia te mieszczą się w szerszej grupie prac dotyczących wpływu posiadania różnych gatunków zwierząt na poziom aktywności fizycznej właścicieli (Oka, Shibata, 2009; Owen i in., 2010; Thorpe Jr i in., 2006; Yabrof, Troiano i Berrigan, 2008; Yam i in., 2012). Szeroka grupa prac dotyczy wykorzystania psów w służbach mundurowych, w tym w policji, m.in. w bardzo młodej dziedzinie kryminalistyki - osmologii (Gondorowicz, 2018).

\section{MATERIAŁY I METODY ORAZ PODSTAWOWE POJĘCIA Z ZAKRESU TROPIENIA UŻYTKOWEGO}

Spośród metod badawczych stosowanych w opracowaniach rekreacji, do identyfikacji osób uprawiających tropienie użytkowe w Polsce wybrano sondaż diagnostyczny. Zastosowano technikę badawczą kwestionariusza ankiety w formie formularza Google, do którego link umieszczony został w treści wiadomości przesłanych indywidualnie do każdego z członków grupy „Tropienie użytkowe / Mantrailing Poland”, funkcjonującej na portalu internetowym Facebook. Jest to grupa publiczna, licząca około 2400 członków (2020) i, jak wynika z opisu, entuzjastów tropienia użytkowego, używających wspomnianej platformy do wymiany informacji o imprezach tropieniowych, szkoleniach, seminariach, obozach, sprzęcie itp. Kwestionariusz ankiety wypełniło 105 osób.

Ankietyzację przeprowadzono w okresie 11.02.2020-9.04.2020. Poprzedzono ją obserwacjami terenowymi, aktywnym uczestnictwem autorów w mantrailingu oraz rozmowami z organizatorami i uczestnikami warsztatów na przełomie 2019 i 2020 roku. Kwestionariusz obejmował 24 pytania główne (16 zamkniętych i 8 otwartych) oraz metryczkę (18 zagadnień).

Pojęciami użytymi w niniejszym opracowaniu, istotnymi dla wyjaśnienia specyfiki tropienia użytkowego są (m.in. za Górny, 2010):

1. Ślad - mieszanina elementów widocznych (przedmiotów) i niewidocznych gołym okiem (np. łusek naskórka, kropelek potu), pozostawionych przez człowieka poruszającego się w terenie. Na ślad składają się także elementy terenu przekształcone na skutek kontaktu z człowiekiem (zgnieciona trawa, złamane gałązki itp.). 
2. Deptacz (układacz) - osoba, która przygotowuje ślad, który później wykorzystuje pies tropiący w celu odnalezienia szukanej osoby lub przedmiotu. Deptacz może pozostawić w terenie przedmioty (gałganki, patyczki itp.) przesiąknięte swoim zapachem.

3. Zapach podstawowy (pierwszorzędny) - zapach elementów naniesionych przez człowieka, niepowtarzalny, przypisany tylko jednemu człowiekowi. Cząsteczki złuszczonego naskórka osoby układającej ślad, opadają grawitacyjnie, są lekkie, unoszone wiatrem, więc osadzają się często daleko od miejsca, po którym poruszał się deptacz.

4. Zapach dodatkowy (drugorzędny) - charakteryzuje dane podłoże - zapach elementów terenu zmienionych na skutek kontaktu z człowiekiem, czyli mieszanka zapachów podłoża naruszonego przez deptacza (np. zapach zgniecionej trawy, połamanych gałązek itp.). Jest dokładnie w tych miejscach, gdzie układacz stawiał kroki. Zapach dodatkowy jest taki sam dla każdego człowieka poruszającego się w danym terenie, a inny dla tego samego człowieka chodzącego po różnych podłożach.

5. Praca dolnym wiatrem - pies pracuje nosem przy podłożu, gdyż wiatr dolny to zdolność odnajdywania człowieka lub zwierzyny (chwytania odwiatru) po tropach i innych śladach.

6. Praca górnym wiatrem - pies węszy z podniesioną głową, gdyż wiatr górny to zdolność zwietrzenia poszukiwanego człowieka lub zwierzyny nie podążając po pozostawionym śladzie, lecz wskazując, gdzie znajduje się w linii prostej.

Naturalnym dążeniem każdego psa jest poszukiwanie największego stężenia cząsteczek interesującego go zapachu, czyli znalezienie jego źródła. W treningu psa tropiącego, wyszukiwane są przede wszystkim elementy składające się na indywidualny zapach poszukiwanego człowieka. Ten niepowtarzalny zapach pochodzi z:

1. Komórek naskórka.

2. Komórek pochodzących z układu oddechowego i trawiennego.

3. Wydzielin produkowanych przez gruczoły skóry:

a) potowe ekrynowe, występujące na całej powierzchni skóry i biorące udział w regulacji temperatury ciała, wydzielające przezroczystą wodnistą i bezwonną ciecz;

b) potowe apokrynowe, zlokalizowane głównie pod pachami i w okolicy genitaliów, wydzielające nieprzezroczystą lepką ciecz. Bakterie żyjące na skórze rozkładają wydzielinę tych gruczołów, a produktami jej rozkładu są cząsteczki związków chemicznych o silnym zapachu;

c) łojowe, znajdujące się na całej powierzchni skóry, oprócz stóp i dłoni. Ich tłusta wydzielina (łój) nie ma zapachu, ale na powierzchni skóry podlega rozkładowi bakteryjnemu, w wyniku którego powstają kwasy tłuszczowe, odznaczające się dosyć intensywnym zapachem. To właśnie skład tych kwasów tłuszczowych uważa się powszechnie za przyczynę niepowtarzalnego indywidualnego zapachu osobnika.

Psi nos doskonale rejestruje zmiany składu substancji chemicznych, ale przykładowo ulewny deszcz zmywa cząsteczki zapachu, a głęboki śnieg utrudnia psu dostęp do cząsteczek, zakonserwowanych w kryształkach lodu. Zapach unosi się z ciepłym powietrzem wzdłuż nagrzanych powierzchni i opada z zimnym. Wysokie ciśnienie „przydusza" cząsteczki zapachu do podłoża, a jego spadek je uwalnia, wzmacniając woń ścieżki 
śladu. Dodatkowo, wysoka temperatura i niska wilgotność zmniejszają aktywność bakterii i na skutek tego zapach „zasycha”.

\section{MANTRAILING I INNE FORMY TROPIENIA}

Istnieje kilka aktywności psa, opartych na węchu, które na potrzeby niniejszego opracowania wydzielono na podstawie nielicznej grupy opublikowanych prac, regulaminów oraz konsultacji z osobami współpracującymi z psami. Nie jest to ścisła delimitacja, nie tylko z powodu różnic definicji „tropienia” wśród obcojęzycznych autorów opracowań na temat psiej aktywności, także ze względu na przenikające się zawodowe lub sportowo-rekreacyjne formy współpracy psa i człowieka.

1. Tracking (tropienie sportowe). W tropieniu sportowym pies tropi po zapachu zdeptanego podłoża, czyli powinien podążać dokładnie po linii, którą przemieściła się osoba „układająca” ślad. Pies porusza się dokładnie śladem człowieka, ale co ciekawe, nie musi znać zapachu osoby, która zostawiła ślad, wystarczy, że zostanie wprowadzony na trop. Jeśli ślad zostanie przecięty przez świeższy ślad, pies powinien na niego skręcić. W tropieniu sportowym istotny jest przede wszystkim styl pracy psa, czyli precyzja „wypracowywania śladu”, w tym praca dolnym wiatrem, nieodchodzenie z linii śladu, nieścinanie zakrętów, zaznaczanie znalezionych przedmiotów itp.

2. Mantracking ( $\mathrm{w}$ Polsce = tropienie sportowe). $\mathrm{W}$ tej formie aktywności pies tropi konkretną osobę po zapachu zdeptanego podłoża. Pies tropi po miękkim podłożu nieznaną osobę, wskazuje nosem bardzo dokładnie miejsca, gdzie układacz postawił stopy. W przeszłości (było mniej twardego podłoża, np. w miastach) te umiejętności były wykorzystywane w pracy np. policji, obecnie bardziej w strzeżeniu granic itp.

3. Tropienie po farbie (użytkowość myśliwska). Pies koncentruje się tylko na zapachu farby - krwi zwierzęcia.

4. Poszukiwanie. Pies poszukiwawczy jest nauczany tropienia zapachu każdego żywego człowieka, głównie w otwartym terenie, gdzie jest mało ludzi. Przewodnik potwierdza czy znaleziona przez psa osoba jest poszukiwaną. Psy pracują górnym wiatrem, zazwyczaj luzem i w wyznaczonych sektorach. W Polsce psy poszukiwawcze są wykorzystywane przez Państwową i Ochotniczą Straż Pożarną, a szkolone i certyfikowane w dwóch specjalnościach: terenowej i gruzowiskowej.

5. Nosework i brainwork. W tych formach aktywności psa praca nosem zmierza do rozpoznania określonych zapachów. Mogą to być zarówno ładunki wybuchowe, narkotyki i inne niedozwolone substancje, jak i w wersji sportowo-rekreacyjnej ukryte i przygotowane wcześniej próbki, smakołyki itp.

6. Tropienie użytkowe (mantrailing). Celem aktywności psa w mantrailingu jest wyłącznie znalezienie konkretnego człowieka (układacza) lub przedmiotów pozostawionych przez niego na śladzie, a nie styl pracy psa, jak przykładowo w tropieniu sportowym. Dla części uczestników tropienia użytkowego pozostawienie przedmiotów przez układacza nie jest warunkiem koniecznym. Tropienie użytkowe polega na podążaniu za zapachem podstawowym, odnajdywaniu jego maksymalnej koncentracji. Ponieważ cząsteczki zapachu człowieka nie opadają pionowo na ziemię, ale są przenoszone prądami powietrza, to ich największa koncentracja wcale nie musi być na śladzie, ale w jego pobliżu. Pies przemieszcza się więc nie zawsze 
po linii prostej. Gdy zgubi zapach, pojawiają się zygzaki i pętle, do momentu aż upewni się, że odnalazł właściwy zapach i kierunek, w którym ma podążać. Może pracować z nosem przy podłożu (dolnym wiatrem) albo węszyć z podniesioną głową (górnym wiatrem), a w danym momencie zależy to od otoczenia, jakie napotkał pies jak i jego charakteru. W pierwszym etapie tropienia użytkowego po wybranej i odpowiednio przygotowanej trasie przechodzi deptacz. Realizuje on ślad, czyli przykładowo gubi przedmioty przesiąknięte swoim zapachem. W etapie drugim, np. po 1-2 godzinach, śladem rusza tandem tropicieli, czyli pies z przewodnikiem, w celu odnalezienia deptacza lub deptacza i pozostawionych przez niego przedmiotów. Przewodnik może usłyszeć też opowieść o zaginięciu osoby, którą pies będzie poszukiwał. Tandem przemieszcza się tempem narzuconym przez psa, a przewodnik stara się nie przeszkadzać i interweniuje dopiero w ostateczności. W trzecim etapie mantrailingu, za tandemem tropicieli może wyruszyć grupa obserwatorów/sędziów, która nie może przebywać zbyt blisko pracującego zwierzęcia, żeby go nie rozpraszać.

\section{UCZESTNICY TROPIENIA UŻYTKOWEgO W POLSCE}

W przeprowadzonym badaniu ankietowym grupy „Tropienie użytkowe/Mantrailing Poland" dążono do reprezentatywności badanej populacji dla środowiska osób uprawiających mantrailing w Polsce. Wśród ankietowanych samo tropienie użytkowe uprawia 89,4\% respondentów, a w połączeniu z tropieniem sportowym i myśliwskim dodatkowo 5,8\%. Tylko w pojedynczych przypadkach są to wyłącznie amatorzy tropienia sportowego $(2,9 \%)$ lub myśliwskiego $(1,9 \%)$. Badaną populację stanowią osoby, które uprawiają, bądź uprawiały mantrailing: dłużej niż 5 lat $(18,1 \%)$, od roku do pięciu lat (56,2\%) oraz krócej niż jeden rok $(25,7 \%)$.

Ankietowani zaliczyli mantrailing do aktywności całorocznych. Wyłącznie w sezonie letnim uprawia go niecałe 5\% respondentów. Określono tę formę rekreacji jako czynności plenerowe, w każdych warunkach terenowych ( $9 / 10$ ankietowanych) lub plenerowe realizowane tylko w określonych warunkach terenowych.

Stosunek członków rodziny do zainteresowań mantrailingiem ankietowani ocenili jako pozytywny lub neutralny i tylko w dwóch przypadkach na ponad 100 ankietowanych, psia pasja respondentów spotkała się z negatywnym odbiorem. Początków zainteresowania respondentów mantrailingiem nie należy jednak upatrywać w zachęcie ze strony członków rodziny (tylko 11,4\% przypadków). Głównymi źródłami informacji o tropieniu użytkowym, na początku przygody z tą formą rekreacji, był Internet (fora, portale społecznościowe, strony www) $(27,6 \%)$, kursy, seminaria, warsztaty i szkolenia $(23,8 \%)$ oraz bezpośrednio znajomi. Wiedza uzupełniana jest informacjami od weterynarzy i behawiorystów lub z branżowych książek i czasopism.

Ważnym elementem opisu sylwetki osoby uprawiającej mantrailing jest częstotliwość, z jaką wyrusza w teren ze swoim psim partnerem. W Polsce jedynie 7\% ankietowanych deklaruje codzienną aktywność fizyczną, 33\% czyni to raz w tygodniu, 12\% rzadziej, ale przynajmniej raz w miesiącu, natomiast reszta sporadycznie bierze udział w jakichkolwiek zajęciach służących podniesieniu sprawności fizycznej (Witek, 2011). Amatorzy tropienia użytkowego wykazują się zdecydowanie większą systematycznością w zakresie aktywności fizycznej niż notowaną w krajowych statystykach. Dotyczy to zarówno samego mantrailingu (rycina 1), jak i innych form aktywności (tabele 1, 2, 3). 
Rycina 1. Częstotliwość uprawiania mantrailingu w Polsce [\%]

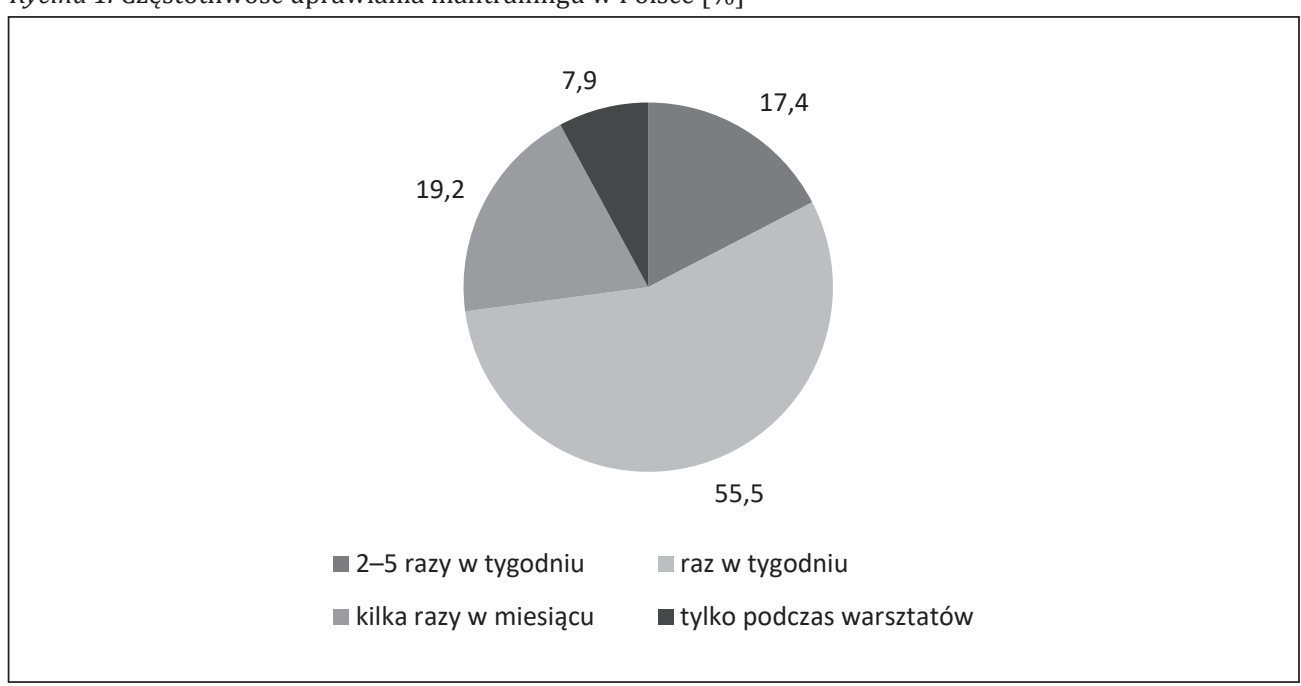

Źródło: opracowanie własne

Tabela 1. Częstotliwość wykonywania ćwiczeń fizycznych osób uprawiających mantrailing w Polsce [\%]

\begin{tabular}{|l|r|}
\hline 3-5 razy w tygodniu i częściej & 54,3 \\
\hline $1-2$ razy w tygodniu & 23,8 \\
\hline rzadziej niż jeden raz w miesiącu & 7,6 \\
\hline wcale & 14,3 \\
\hline
\end{tabular}

Źródło: opracowanie własne

Tabela 2. Czas przeznaczany jednorazowo na aktywność osób uprawiających mantrailing w Polsce [\%]

\begin{tabular}{|l|r|}
\hline nie podejmuję aktywności fizycznej & 11,4 \\
\hline do pół godziny & 5,7 \\
\hline od pół godziny do godziny & 32,4 \\
\hline jedna do dwóch godzin & 42,9 \\
\hline ponad dwie godziny & 7,6 \\
\hline
\end{tabular}

Źródło: opracowanie własne

Tabela 3. Typy aktywności fizycznej osób uprawiających mantrailing w Polsce (wielokrotny wybór) [\%]

\begin{tabular}{|l|c|}
\hline jazda na rowerze & 21,0 \\
\hline bieganie & 20,0 \\
\hline spacery & 19,0 \\
\hline inne aktywności z psem & 13,3 \\
\hline ćwiczenia siłowe (siłownia, ćwiczenia w domu) & 15,2 \\
\hline praca w ogrodzie & 11,4 \\
\hline pływanie & 10,5 \\
\hline $\begin{array}{l}\text { Inne (poniżej 10\%): joga, jazda konna, sztuki walki, wspinaczka, NW, triathlon, skituring, } \\
\text { trekking, taniec, surfing, fitness }\end{array}$ & 22,8 \\
\hline
\end{tabular}

Źródło: opracowanie własne 
Amatorzy mantrailingu, biorąc pod uwagę intensywność wysiłku i stosując delimitację Toczek-Werner (1999), zaliczają go do średnio intensywnych czynności człowieka (56,2\%), przypisanych w pytaniu ankietowym do takich aktywności jak jazda na łyżwach czy gimnastyka. Znaczna grupa wybrała poziom zajęć relaksacyjnych, kojarzonych ze spacerowaniem i wędkowaniem. Podobnie, ze względu na stopień trudności (złożoności technicznej) (Toczek-Werner, 1999) większość osób mantrailing zaliczyła do czynności średnio trudnych $(51,4 \%$ ) (w pytaniu porównane do piłki nożnej, jazdy na łyżwach). Jedna trzecia uznała go jako trudne (jazda na nartach, wspinaczka), a pozostali jako łatwe (bieganie, jazda na rowerze).

Osoby uprawiające mantrailing poproszono o dokonanie samooceny stanu zdrowia i kondycji fizycznej, umieszczając sześć dodatkowych pytań w metryczce. Zdecydowana większość ankietowanych określiła swój stan zdrowia jako zadawalający, w tym połowa jako dobry, $1 / 3$ jako bardzo dobry. Ponad $2 / 3$ respondentów na pytanie czy oceniają się jako osobę sprawną fizycznie odpowiedziało, że raczej tak, a prawie $1 / 3$, że zdecydowanie tak. Wyłączając ze statystyk $40 \%$ badanych, którzy deklarowali, że nie doświadczają problemów zdrowotnych, w pozostałej grupie definiowano w kolejności: wady wzroku, choroby narządu ruchu, układu trawiennego, układu oddechowego, układu krążenia oraz zaburzenia psychiczne.

Współczesny postęp cywilizacyjny spowodował większe zainteresowanie aktywnościami wolnoczasowymi, przy czym im wyższy poziom wykształcenia, tym większa świadomość i troska o zdrowie, które zagrożone jest przez choroby cywilizacyjne (Lubowiecki-Vikuk, Paczyńska-Jędrycka, 2010). Zdecydowanie wśród amatorów mantrailingu przeważa wykształcenie wyższe (magisterskie 67,6\%, licencjackie 16,2\%). Osiem na dziesięć osób uprawiających tropienie użytkowe w Polsce pochodzi z miasta. Największą grupę stanowią osoby z przedziałów wiekowych: 25-44 lata (73,3\%) oraz 45-64 lata (19\%). Wśród amatorów mantrailingu w Polsce 85\% stanowią kobiety. Większość respondentów oceniła pozytywnie swoją sytuację materialną (raczej dobra - 68,6\%, zdecydowanie dobra $-25,7 \%$ ). Są to osoby pracujące przeważnie w firmie prywatnej lub prowadzące własną działalność gospodarczą. Bardzo nieliczną grupę stanowią przykładowo emeryci i renciści $(3,8 \%)$ oraz uczniowie i studenci $(7,6 \%)$.

Sposobów wykorzystywania psów, ukształtowanych na przestrzeni wieków, jest tak wiele, jak wiele jest ras i ich podziałów pod kątem różnych cech i predyspozycji (Jędrzejczak, Pęzińska-Kijak, 2017). Wśród osób uprawiających mantrailing na terenie Polski nie ma zgodności co do preferowanych ras psów. Statystycznie, w wariancie odpowiedzi tak/nie, mniej niż w połowie przypadków respondent uważał, że istnieją rasy przez niego preferowane $w$ tropieniu użytkowym. Co więcej, nawet $w$ tej grupie co prawda najczęściej wymieniał owczarka niemieckiego, owczarka belgijskiego malinoisa lub używał szerszego sformułowania „psy ras myśliwskich”, ale przy bardzo szerokiej gamie innych wymienionych ras (aż 59,2\%).

\section{MotyWy TROPIENIA UŻYTKOWEgo W POLSCE}

W wyniku przeprowadzonych badań ankietowych stwierdzono, że podstawowymi motywami uprawiania mantrailingu w Polsce jest określenie potrzeb i predyspozycji psa, a wśród motywów aktywności przyjętych w literaturze przedmiotu - motyw poznawczy (rycina 2). 
Rycina 2. Motywy uprawiania mantrailingu w Polsce [\%]

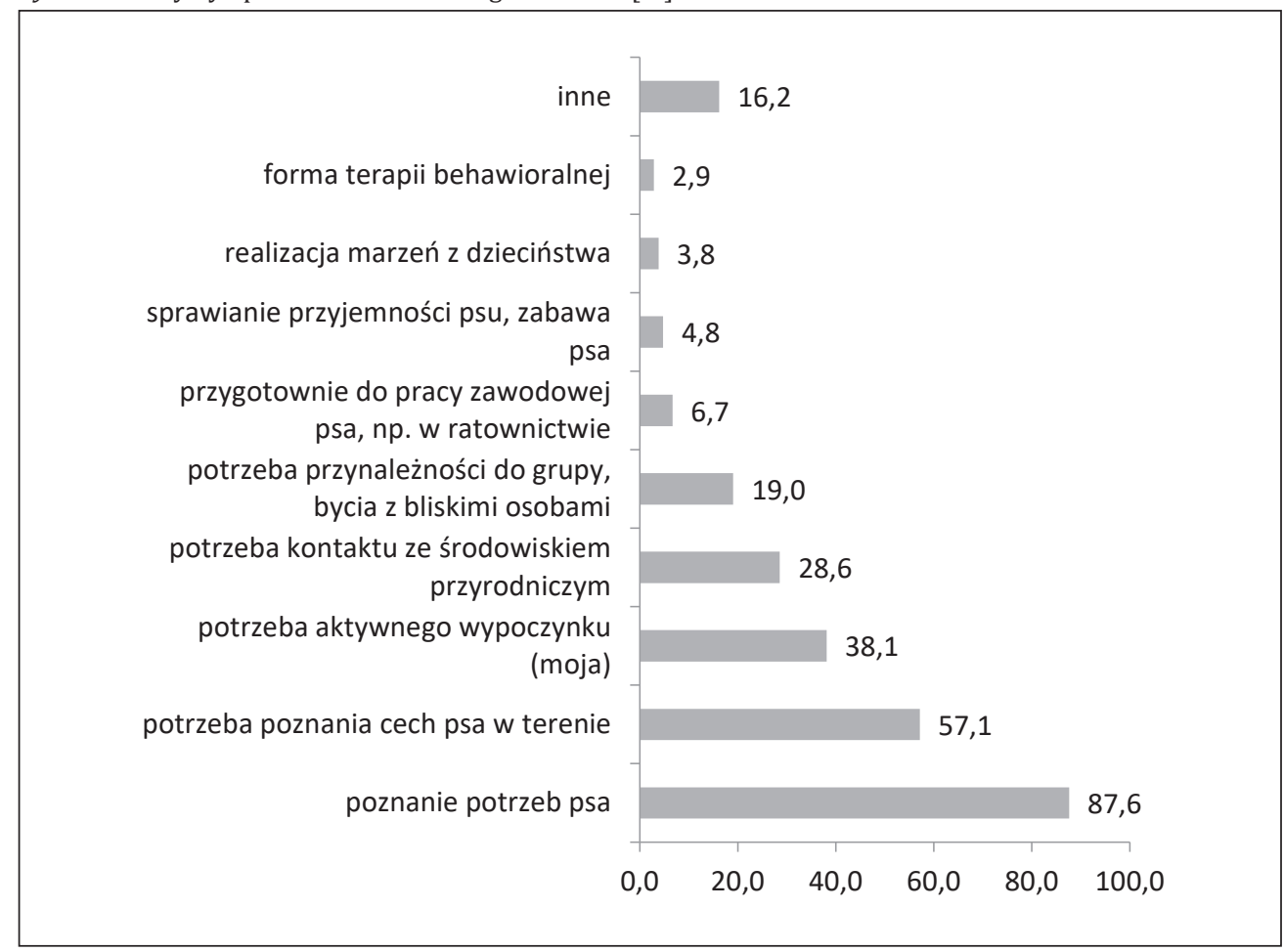

Źródło: opracowanie własne

Wśród szerokiej gamy funkcji rekreacji ruchowej, w przypadku mantrailingu ankietowani wskazywali w kolejności: wypoczynkową (79\%), kształceniową (67\%), zdrowotną $(23,8 \%)$, wychowawczą $(22,9 \%)$ oraz edukacji kulturowej $(3,8 \%)$.

Dla większości osób uprawiających mantrailing (61\%) zdawanie egzaminów i uzyskiwanie certyfikatów w zakresie tropienia nie jest istotne. Członkowie badanej grupy byli w posiadaniu uprawnień PLMT1 (Polski Certyfikat Tropienia Użytkowego) $(9,5 \%)$, PLMT2 (8,6\%), PLMT3 (3,8\%) oraz PSP (uprawnienia Państwowej Straży Pożarnej), IRO (certyfikat Internationale Rettungshunde Organisation) i SKOP (Sprawdzian Kompetencji Zespołów Tropienia Użytkowego) (1\%). Wśród amatorów mantrailingu dostrzegających ważność pozyskiwania certyfikatów dominowały argumenty: sprawdzianu i weryfikacji umiejętności nabytych na treningach, wyznaczenia dodatkowego celu, motywacji do udziału w treningach, chęci pomocy poszkodowanym po uzyskaniu uprawnień oraz własnej satysfakcji.

Na pytanie, czy aspekt rywalizacji ma miejsce pomiędzy uczestnikami mantrailingu i czy jest dla nich istotny tylko 3\% osób odpowiedziało twierdząco. Pozostali ankietowani albo uważają, że takie zjawisko nie istnieje lub że je zaobserwowali, ale nie jest dla nich istotne. Co więcej, wskazano, że rywalizacja jest nieuzasadniona ze względu na brak możliwości porównywania kolejnych „śladów”. Nawet trening w tym samym miejscu, ale o innej porze dnia, jest już doświadczeniem, którego nie da się porównać do poprzednich. Amatorzy mantrailingu zwracają uwagę, iż nadmierna konkurencja zniszczyła wiele form rekreacji, szczególnie psich, doprowadziła do atomizacji środowiska, 
gdzie coraz mniej liczy się udział w wydarzeniu, a rośnie znaczenie wygranej. Argumentują, że rywalizacja może przeszkadzać w prowadzeniu grupy, wpływa negatywnie na psy, na które nakładana jest zbyt duża presja.

Mantrailing, co wykazano w dodatkowym pytaniu, w przypadku 41\% ankietowanych jest dla ich psów działaniem uzupełniającym lub przygotowującym dla innej aktywności. Zestawienie form rekreacji, sportu lub rehabilitacji, z którymi czynnie zetknęli się ankietowani zawiera tabela 4. Listę ośmiu najczęściej wymienianych aktywności uzupełniają formy takie jak: dogoterapia, bikejoring, scooter lub jazda za psem na łyżworolkach, zaganianie owiec, rally obedience, coursing lub flyball, dog dancing, dog frisbee (freestyle), dummy, przeciąganie, dog fitness, high jump lub wall climbing, podnoszenie ciężarów, ratownictwo, psie zaprzęgi lub pulka.

Tabela 4. Formy rekreacji, sportu lub rehabilitacji z psem uprawiane obecnie lub w przeszłości przez amatorów tropienia użytkowego w Polsce [\%]

\begin{tabular}{|l|c|}
\hline nosework & 52,4 \\
\hline dogtrekking & 45,7 \\
\hline detekcja węchowa & 41,0 \\
\hline wystawy & 17,1 \\
\hline canicross & 16,2 \\
\hline obedience & 16,2 \\
\hline dog frisbee & 14,3 \\
\hline agility & 12,4 \\
\hline inne & poniżej 10 \\
\hline
\end{tabular}

Źródło: opracowanie własne

Amatorzy mantrailingu mieli możliwość określenia, na jakie sfery życia człowieka ma wpływ ich pasja w kontekście poprawy jego jakości. Straś-Romanowska (1992) wydzieliła cztery wymiary jakości życia: psychospołeczny, psychofizyczny, podmiotowy i metafizyczny, a więc duchowy. Sfera psychofizyczna dotyczy szeroko pojętej cielesności, popędowości człowieka. Sfera psychospołeczna (zwana także społeczną) zapewnia poczucie przynależności, bezpieczeństwa i tożsamości społecznej. Przejawem sfery podmiotowości jest realizacja osobistych zainteresowań, celów, pomagająca w osiągnięciu samorealizacji i życia autentycznego. Sfera metafizyczna obejmuje ponadczasowe wartości, takie jak dobro, prawda, miłość itp. Amatorzy mantrailingu najczęściej wymieniali sfery: podmiotowości $(78,1 \%)$, psychospołeczną $(44,8 \%)$, psychofizyczną (biologiczną) $(43,8 \%)$ oraz bezpieczeństwa (29,5\%). Wśród cech charakteru człowieka, na kształtowanie których wpływa mantrailing, zdecydowanie najczęściej wymieniano cierpliwość. Wskazywano także odpowiedzialność, niezależność, uważność, pokorę, spostrzegawczość, umiejętność czytania i zaufania do psa, opanowanie i pewność siebie.

Na przestrzeni wieków nie tylko zmieniła się rola psa w życiu człowieka, ale przede wszystkim stosunek do niego - właściciele nie tylko chcą nauczyć się lepszego współżycia z nim, ale nawiązać silną więź i porozumienie. Tylko co piąty ankietowany na pytanie czy w mantrailingu bardziej sprawdza siebie czy psa wskazał na czworonoga. Wyłączając osoby zaskoczone taką formą pytania, zdecydowana większość traktuje mantrailing jako formę obserwacji w terenie siebie i psa $(37,1 \%)$ lub siebie $(31,4 \%)$. 
Dziewięciu na dziesięciu amatorów mantrailingu deklaruje, iż ta forma rekreacji pomogła im we właściwym „czytaniu” swojego psa. Do głównych argumentów należały:

- poprawa komunikacji, wzajemnej obserwacji, zwiększenie obustronnego zaufania;

- możliwość szybszej reakcji na zachowanie psa;

- pomoc w zrozumieniu emocji, specyficznych cech psów, problemów z koncentracją;

- umożliwienie psu więcej samodzielnych decyzji;

- możliwość szerszej obserwacji stanów podekscytowania, koncentracji, stresu;

- zwracanie uwagi na dużą liczbę szczegółów w krótkim czasie;

- rozróżnianie, kiedy pies szuka, gdy się gubi, prosi o pomoc, jest zmęczony, spłoszony.

Co ważne, tropienie użytkowe, zdaniem ich właścicieli (61\%), pełni funkcję terapeutyczną dla psa. Dotyczy to m.in.:

- podniesienia pewności siebie, nauki kontroli emocji, wyciszania psa;

- budowania samodzielności psa, pomocy w radzeniu sobie z trudnymi sytuacjami;

- konstruktywnego reagowania na innych ludzi (pozorantów);

- uzupełniania terapii behawioralnej, niwelowania problemów z czasów szczenięcych.

Ze względu na pożądane jak najszersze uczestnictwo społeczeństwa w turystyce i rekreacji, priorytetowym kierunkiem w badaniach nad aktywnością społeczeństwa staje się zjawisko „ekskluzji turystycznej” (Alejziak, 2009). Należy zastanowić się więc nad faktem ograniczeń możliwości uprawiania mantrailingu w Polsce. Zdaniem połowy ankietowanych osób głównymi „hamulcami” tropienia użytkowego są głównie brak środków finansowych i wolnego czasu, wynikający z obowiązków domowych i służbowych oraz skromna oferta „obozów mantrailingowych”. Stosunkowo niewielu amatorów mantrailingu uskarża się natomiast na błędy organizacyjne i nieprzygotowanych instruktorów oraz ograniczony dostęp do miejsc, gdzie można go uprawiać.

\section{PodsumOWANIE}

Mantrailing wpisuje się w definicję rekreacji ruchowej i jest rozwijającym się dynamicznie w Polsce zjawiskiem społeczno-kulturowym, związanym ze zwiększeniem się ilości czasu wolnego oraz zmianami sposobów jego spędzania. Jest to forma rekreacji czynnej, ale z niewielką przewagą wysiłku fizycznego, zaliczana do całorocznych czynności plenerowych, w każdych warunkach terenowych. Nosi również znamiona rekreacji twórczej oraz rekreacji rozumianej w literaturze przedmiotu jako działalność kulturalno-rozrywkowa i społeczna. W przypadku psów jest to rekreacja silnie nacechowana emocjami. Zwierzęta ekscytują się po dotarciu do poszukiwanej osoby z bardzo różnych powodów, wypijają hektolitry wody, eksponują języki.

Podstawowymi motywami uprawiania mantrailingu w Polsce jest określenie potrzeb i predyspozycji psa oraz chęć poznania jego zachowań bezpośrednio w warunkach pracy w terenie. Nie jest to natomiast uzyskiwanie certyfikatów w zakresie tropienia. Co istotne, rozwijanie sprawności fizycznej i dążenie do uzyskiwania jak najlepszych wyników przez zespół mantrailingowy, odbywa się w warunkach pominięcia aspektu współzawodnictwa, bardzo istotnego w sporcie. Wśród szerokiej gamy funkcji mantrailingu wskazywana jest głównie wypoczynkowa i kształceniowa. 
Potwierdzono zespół głównych zalet mantrailingu, na tle innych psich form aktywności, jak praca psa zgodna z jego naturą, wykorzystywanie podanych psu rekwizytów do ciężkiej pracy intelektualnej, zróżnicowanie terenu ćwiczeń w zależności od zaawansowania psa oraz walor ćwiczeń kondycyjnych właściciela i niewielkie ograniczenia co do rasy psa i stanu psychofizycznego psa i człowieka.

Osoby zainteresowane mantrailingiem w Polsce są grupą relatywnie młodą i dobrze wykształconą. Postępowi cywilizacyjnemu towarzyszy wzrost zamożności społeczeństw, co pozwala na realizację potrzeb w czasie wolnym. W tym kontekście amatorzy mantrailingu oceniają pozytywnie swoją sytuację materialną. W zdecydowanej większości pochodzą z miasta, co potwierdza ogólną tendencję, iż ludność miejska jest bardziej aktywna fizycznie. W przypadku tropienia użytkowego potwierdza się również przewaga udziału kobiet w aktywnościach związanych z psami. Zestawienie ras, z którymi ankietowani uprawiają mantrailing nacechowane jest niezwykłą różnorodnością, przy braku ścisłej listy tych, które uważają za preferowane w tej formie rekreacji.

Nie można uogólniać na całą społeczność mantrailingową w Polsce powyższych wyników badania ankietowego. Mają one charakter eksploracyjny, preorientacyjny. Tematyka tropienia użytkowego wymaga dalszych szczegółowych badań, uwzględniających między innymi aspekt przestrzenny oraz interakcje społeczne, spowodowane obecnością psa. Stanowią uzupełnienie rozważań na temat promocji zdrowia i aktywności fizycznej.

Autorzy artykułu serdecznie dziękują Iwonie Abrahamowicz i Ilonie Al-Mutari (Mam w Nosie - Grupa tropiąca Kraków) za pomoc i cenne uwagi w przygotowaniu formularza ankiety.

\section{Literatura}

References

Alejziak, W. (2009). Determinanty i zróżnicowanie społeczne aktywności turystycznej. Kraków: Akademia Wychowania Fizycznego im. Bronisława Czecha, 433-434 (Studia i Monografie AWF, 56).

Chochowski, W. (2015, 9 grudnia). Tropienie użytkowe. Pozyskano z http://www.polska.hovawart.pl/index.php/hovawart-quytecznyq/sportowo-szkoleniowo/1056-tropienie-uzytkowe (dostęp 1.08.2019).

Christian, H.E., Westgarth, C., Bauman, A., Richards, E.A., Rhodes, R.E., Evenson, K.R, Mayer, J.A., Thorpe, Jr R.J. (2013). Dog ownership and physical activity. A review of the evidence. Journal of Physical Activity \& Health, 10(5), 750-759.

Cichy, A., Medeńska, W., Dratwa-Chałupnik, A., Lepczyński, A., Michałek, K., Herosimczyk, A., Skrzypczak, W.F., Ożgo, M., Marynowska, M. (2018). Psi węch jako detektor. W: K.M. Kavetska (red.), Pies w służbie. Czwarte warsztaty kynologiczne. Zakład Karny w Goleniowie, 18 maja 2018. Szczecin: Zachodniopomorski Uniwersytet Technologiczny w Szczecinie.

Cutt, H., Giles-Corti, B., Knuiman, M., Burke, V. (2007). Dog ownership, health and physical activity. A critical review of the literature. Health \& Place, 13(1), 261-272.

Cutt, H.E., Knuiman, M.W., Giles-Corti, B. (2008). Does getting a dog increase recreational walking? International Journal of Behavioral Nutrition and Physical Activity, 5, 17.

Dąbrowski, A. (red.). (2006). Zarys teorii rekreacji ruchowej. Warszawa: Almamer Wyższa Szkoła Ekonomiczna; Akademia Wychowania Fizycznego.

Dłużewska, A., Gonia, A., Michniewicz-Ankiersztajn, H., Podgórski, Z. (2015). Współczesne problemy turystyki. Bydgoszcz; Poznań: Ośrodek Rekreacji, Sportu i Edukacji w Poznaniu, 135-156.

Guéguen, N., Ciccotti, S. (2008). Domestic Dogs as Facilitators in Social Interaction. An Evaluation of Helping and Courtship Behaviors. Anthrozoös, 21, 339-349. 
Gondorowicz, M. (2018). Wykorzystanie psiego nosa w kryminalistyce, czyli słów kilka o osmologii w Polsce. W: K.M. Kavetska (red.), Pies w służbie. Czwarte warsztaty kynologiczne. Zakład Karny w Goleniowie, 18 maja 2018. Szczecin: Zachodniopomorski Uniwersytet Technologiczny w Szczecinie.

Górny, B. (2010). Nowoczesne szkolenie psów tropiących. Warszawa: Multico Oficyna Wydawnicza.

Jastrzębska, A., Gugołek, A., Strychalski, J. (2017a). Zwierzęta w sporcie, rekreacji i rozrywce (cz. 1). Wiadomości Zootechniczne, 55(1), 87-93.

Jastrzębska, A., Gugołek, A., Strychalski, J. (2017b). Zwierzęta w sporcie, rekreacji i rozrywce (cz. 2). Wiadomości Zootechniczne, 55(2): 173-181.

Jędrzejczak, M., Pęzińska-Kijak, K. (2017). Związek między człowiekiem i psem - kształtowanie zachowań metodą pozytywną. W: K.M. Kavetska (red.), Szkolenie i użytkowanie psów. Trzecie Warsztaty Kynologiczne, Szczecin, 6-7 października 2017. Szczecin: Zachodniopomorski Uniwersytet Technologiczny w Szczecinie.

Johnson, G.R. (2003). Tracking Dog. - Theory and Methods. Mechanicsburg, PA: Barkleigh Productions.

Kwilecka, M. (red.). (2006). Bezpośrednie funkcje rekreacji. Warszawa: Almamer Wyższa Szkoła Ekonomiczna.

Lipowski, M. (2006). Rekreacja ruchowa kobiet jako zachowanie prozdrowotne - uwarunkowania a motywy uczestnictwa. Gdańsk: Wydawnictwo Uczelniane Akademii Wychowania Fizycznego i Sportu.

Lubowiecki-Vikuk, A.P., Paczyńska-Jędrycka, M. (2010). Współczesne tendencje w rozwoju form rekreacyjnych i turystycznych. Poznań: Bogucki Wydawnictwo Naukowe.

McNicholas, J., Collis, G.M. (2000). Dogs as catalysts for social interactions. Robustness of the effect. British Journal of Psychology, 91(1), 61-70.

McNicholas, J., Gilbey, A., Rennie, A., Ahmedzai, S., Dono, J-A., Ormerod, E. (2005). Pet ownership and human health. A brief review of evidence and issues. BMJ, 331, 1252-1254.

Niewiadomska, M. (2018) Forms of activities with a dog as modern types of physical recreation, Central European Journal of Sport Sciences and Medicine, 23(3), 53-58.

Niewiadomska, M., Makris, M. (2015). Sport kynologiczny agility jako forma aktywności fizycznej podejmowana przez ludzi w różnym wieku. Marketing i Rynek, 11, 261-267.

Oka, K., Shibata, A. (2009). Dog ownership and health-related physical activity among Japanese adults. Journal of Physical Activity \&Health, 6(4), 412-418.

Owen, C.G., Nightingale, C.M., Rudnicka, A.R., Ekelund, U., McMinn, A.M., van Sluijs, E.M., Griffin, S., Cook, D.G., Whincup, P.H. (2010). Family dog ownership and levels of physical activity in childhood. Findings from the Child Heart and Health study in England. American Journal of Public Health, 100(9), 1669-1671.

Sjösten, I. (2005). Obedience. Trening posłuszeństwa. Łódź: Wydawnictwo Galaktyka.

Steiger, A. (2006). Pet animals: housing, breeding and welfare. W: Animal Welfare. Strasbourg: Council of Europe Publishing.

Straś-Romanowska, M. (1992). Los człowieka jako problem psychologiczny. Podstawy teoretyczne. Wrocław: Wydawnictwo Uniwersytetu Wrocławskiego.

Strychalski, J., Gugołek, A., Jastrzębska, A. (2016). Psy w sporcie i rekreacji. Przegląd Hodowlany, 84(3), 29-33.

Ščučka, J. (2020, wrzesień) Podstawy szkolenia tropienia metoda kwadratów zapachowych (Natural Canine Communication). Pozyskano z http://docplayer.pl/8821088-Podstawy-szkolenia-tropienia-metoda-kwadratow-zapachowych.html

Teodorowicz, A., Woźniewicz-Dobrzyńska, M. (2014). Sport and recreational activity with a dog. Psychosocial significance of dog owenership. W: F. Dias, S. Oliveira, J. Kosmaczewska, Â. Pereira (red), New trends in tourism research - a polish perspective, 296-310. Pozyskano z http://www.icthr.byd.pl/userfiles/files/Student_Monograph_New\%20Trends\%20in\%20 Tourism\%20Research_final_version\%20-21-10.pdf

Theby, V., Hares, M. (2010). Agility. Sport i zabawa. Warszawa: Wydawnictwo RM.

Thorpe, R.J. Jr, Simonsick, E.M., Brach, J.S., Ayonayon, H., Satterfield, S., Harris, T.B., Garcia, M., Kritchevsky, S.B. (2006). Dog ownership, walking behavior, and maintained mobility in late life. Journal of the American Geriatrics Society, 54(9), 1419-1424. 
Toczek-Werner, S. (1999). Podstawowe formy i metody stosowane w rekreacji ruchowej. W: S. Toczek-Werner (red.). Podstawy rekreacji i turystyki. Wrocław: Wydawnictwo Akademii Wychowania Fizycznego, 21-30.

Witek, J. (2011). Sport i rekreacja a wyzwania współczesnej cywilizacji (wstęp). Ekonomiczne problemy usług, 78, 6-7.

Wolańska, T. (1997). Leksykon. Sport dla wszystkich - rekreacja ruchowa. Warszawa: Wydawnictwo AWF.

Woidtke, L. (2016). Tropienie górnym wiatrem w policji Saksonii. Kwartalnik Policyjny, 3, 70-77.

Yabroff, K.R., Troiano, R.P., Berrigan, D. (2008). Walking the Dog. Is Pet Ownership Associated With Physical Activity in California? Journal of Physical Activity and Health, 5(2), 216-228.

Yam, P.S., Morrison, R., Penpraze, V., Westgarth, C., Ward, D.S., Mutrie, N., Hutchison, P., Young, D., Reilly, J.J. (2012). Children, parents, and pets exercising together (CPET) randomised controlled trial. Study rationale, design, and methods. BMC Public Health, 12(1), 208.

Witold Warcholik, dr, Uniwersytet Pedagogiczny w Krakowie, Instytut Geografii, Katedra Turystyki i Badań Regionalnych Doktor nauk o Ziemi, wykładowca akademicki, autor publikacji z zakresu turystyki, geomorfologii, kartografii i GIS. Miłośnik Krakowa i Beskidu Niskiego, licencjonowany przewodnik miejski i po Ojcowskim Parku Narodowym, pilot wycieczek, instruktor turystyki kwalifikowanej, questingu.

Witold Warcholik, PhD, Pedagogical University of Krakow, Institute of Geography, Department of Tourism and Regional Studies. PhD in Earth Sciences, geodetic engineer, author of several publications on tourism, geomorphology, cartography and GIS, an avid Krakow fan, licensed Krakow city and OPN guide, a tour guide.

ORCID: https://orcid.org/ 0000-0003-3413-582X

\section{Adres/address:}

Uniwersytet Pedagogiczny w Krakowie

Instytut Geografii

Katedra Turystyki i Badań Regionalnych

ul. Podchorążych 2

30-084 Kraków, Polska

e-mail: witold.warcholik@up.krakow.pl

Dorota Chmielowska, dr, Uniwersytet Pedagogiczny w Krakowie, Instytut Geografii, Katedra Geografii Fizycznej. Doktor nauk o Ziemi. Główne obszary zainteresowań to: geografia fizyczna, geomorfologia i sedymentologia. Hobbystycznie uprawia mantrailing w Krakowskiej Grupie Tropiącej „Mam w Nosie”.

Dorota Chmielowska, PhD, Pedagogical University of Krakow, Institute of Geography, Department of Physical Geography. PhD in Earth Sciences in the discipline of geography, specialisation in physical geography, working in the fields of geomorphology and sedimentology. She practices mantrailing as a hobby in "Mam w Nosie" Mantrailing Group in Krakow .

ORCID: https://orcid.org/ 0000-0002-7332-3359

\section{Adres/address:}

Uniwersytet Pedagogiczny w Krakowie

Instytut Geografii

Katedra Geografii Fizycznej

ul. Podchorążych 2

30-084 Kraków, Polska

e-mail: dorota.chmielowska@up.krakow.pl 